\title{
Sycophila pistacina (Hymenoptera: Eurytomidae): A valid species
}

\author{
Hosseinali LOTFALIZADEH ${ }^{2}$, GÉrARd DELVARE ${ }^{*}$ and JEAN-Yves RASPLUS ${ }^{1}$ \\ ${ }^{1}$ INRA CIRAD IRD Centre de Biologie et de Gestion des Populations (CBGP), Campus International de Baillarguet, \\ 34398 Montpellier Cedex 5, France \\ ${ }^{2}$ Department of Insect Taxonomy, Iranian Research Institute of Plant Protection, Tehran, P.O.B. 19395-1454, Iran
}

Key words. Eurytomidae, Sycophila, Sycophila biguttata, S. pistacina, S. iracemae, status revised, parasitoid, morphometrics, molecular phylogeny, COI, ITS2

\begin{abstract}
Sycophila pistacina (Rondani), which was previously synonymized with Sycophila biguttata (Swederus), is revalidated. Morphological, morphometric and molecular data confirm its status as a separate species. Diagnostic characters are provided for distinguishing it from S. biguttata. The nomenclature of the $S$. biguttata complex is updated.
\end{abstract}

\section{INTRODUCTION}

Sycophila includes 11 valid species in Europe, most of which are associated with cynipid galls, especially on Quercus spp. (Noyes, 2002). Mayr (1905), Erdös (1952), Claridge (1959), Nieves-Aldrey (1983), Pujade-Villar (1993) and Zerova (1995) provide identification keys to the Palearctic species, but none of them is exhaustive. Claridge (1959) greatly improved the nomenclature by examining the types of the species described by Curtis (1831), Walker (1832, 1834), Boheman (1836), Thompson (1876) and Mayr (1905). More recently NievesAldrey (1983) and Pujade-Villar (1993) studied the fauna of the Iberian Peninsula. Graham $(1988,1992)$ further updated the nomenclature including the species described by Nees (1834) and Fonscolombe (1832).

Sycophila biguttata (Swederus, 1795) is a common species, widely distributed in the Palearctic region (Noyes, 2002). Its biology is typical of the other European species: Mayr (1905) reared it from galls on oaks caused by 45 cynipids; Nieves-Aldrey (1983) and Pujade-Villar (1993) reared it respectively from 24 and 14 different cynipid galls. The host genera are Andricus, Cynips, Biorhiza and Neuroterus, which generally form galls on the buds of deciduous oaks (Quercus faginea, Q. robur, $Q$. pubescens and $Q$. pyrenaica); S. biguttata is rarely reared from cynipids galls collected on evergreen oaks, such as $Q$. suber in the Mediterranean Region. Askew (1984) records this species as an endoparasitoid of cecidogenic cynipid larvae. Available data (Claridge, 1959; Nieves-Aldrey, 1983) clearly demonstrate that this species is bivoltine, completing one generation in autumn and winter at the expense of the agamous generation of its cynipid host and another generation in spring and early summer at the expense of the sexual generation.

Bouček (1974), in his study of the chalcidoids described by Rondani (1872), deals with a species of eurytomid described as Tineomyza pistacina. Rondani quoted Palumbina guerinii (Stainton) (as P. terebinthella, a junior synonym) - a gelechiid moth infesting the pods of Pistacia terebinthus and P. vera (Mourikis et al., 1998) - as the host of this wasp. Megastigmus pistaciae Walker (Chalcidoidea: Torymidae) is another pest of Pistacia spp., which also develops within the seeds (Davatchi, 1956; Traveset, 1993). It is widely distributed in the Mediterranean Basin and Central Asia and is quoted as a host either of Sycophila biguttata (Nikol'skaya, 1935), or of a species close to it (Davatchi, 1958). Another parasitoid of $M$. pistaciae is described as "Decatoma trogocarpi n. sp.?" (De Stefani, 1908). Our own observations and collection from the South of France and Corsica indicate that $M$. pistaciae and $S$. pistacina are present at the same sites in the same time, either on $P$. terebinthus or $P$. lentiscus.

Further, Nieves-Aldrey (1983) described S. iracemae from specimens reared from Andricus spp. in the Salamanca Region of Spain and subsequently reared from the same host in the Madrid Province (Gómez et al., 2006). The adults all emerged from the agamous generation of the cynipids. Nevertheless it was recently reared in France from galls of Pediaspis aceris (Gmelin) (Askew et al., 2006), which is confirmed by a recent rearing of this parasitoid by one of us (GD) from the sexual form of this cynipid wasp.

Bouček (1974) synonymized T. pistacina with S. biguttata on the basis of intraspecific variation in body color, a feature already quoted by Mayr (1905) and Claridge (1959) for populations reared from cynipid galls on oaks. A number of biological and biogeographic facts led us to challenge this synonymy. First, the endoparasitic habit is considered to be a specialized feature resulting from a long coevolution between a parasitoid and its host. As the hosts belong to different superfamilies (Cynipoidea versus Chalcidoidea) it is hardly conceivable that the same species can overcome the different immune defenses. Second, S. biguttata is clearly bivoltine, while

\footnotetext{
* Corresponding author; e-mail: gerard.delvare@cirad.fr
} 
TABLE 1. Specimens of Sycophila used in the molecular study: collecting site, sample size, obtained sequences (for COI \& ITS2) and codes used.

\begin{tabular}{|c|c|c|c|c|c|}
\hline \multirow{2}{*}{ Species* } & \multirow{2}{*}{ Collection site } & \multirow{2}{*}{$\begin{array}{l}\text { Sample } \\
\text { size }\end{array}$} & \multicolumn{2}{|c|}{ Obtained sequences } & \multirow{2}{*}{ Specimen code } \\
\hline & & & $(\mathrm{COI})$ & (ITS2) & \\
\hline $\begin{array}{l}\text { Eurytoma amygdali } \\
\text { Enderlein }\end{array}$ & $\begin{array}{l}\text { SYRIA: Damas, iii.2005, ex seeds of Amygdalus } \\
\text { cominus }\end{array}$ & 1 & 1 & 1 & H106 \\
\hline $\begin{array}{l}\text { Eurytoma caninae } \\
\text { Lotfalizadeh \& Delvare }\end{array}$ & $\begin{array}{l}\text { IRAN:Azarbayjan-e-Sharghi, Marand, } \\
\text { ex Diplolepis fructuum on Rosa canina }\end{array}$ & 1 & 1 & 1 & H169 \\
\hline \multirow{2}{*}{$\begin{array}{l}\text { Sycophila biguttata } \\
\text { (Swederus) }\end{array}$} & $\begin{array}{l}\text { FRANCE: Var, Sainte-Zacharie, } \\
\text { Sainte-Beaume, swept from Quercus pubescens }\end{array}$ & 3 & 3 & 2 & B3-B4 \\
\hline & $\begin{array}{l}\text { IRAN: Lorestan, Ghalai, } \\
\text { ex Andricus grossulariae on Quercus brantii }\end{array}$ & 20 & 3 & 2 & B6-B9-B11 \\
\hline $\begin{array}{l}\text { Sycophila iracemae } \\
\text { Nieves-Aldrey }\end{array}$ & $\begin{array}{l}\text { FRANCE: Hérault, Saint-Martin-de-Londres, } \\
220 \text { m, swept from Quercus pubescens }\end{array}$ & 2 & 2 & 2 & B1-B2 \\
\hline $\begin{array}{l}\text { Sycophila pistacina } \\
\text { (Rondani) }\end{array}$ & $\begin{array}{l}\text { FRANCE: Hérault, Cazevieille, } \\
230 \text { m, swept from Pistacia terebinthus }\end{array}$ & 15 & 4 & 4 & P5-P6-P7-H179 \\
\hline \multirow{2}{*}{$\begin{array}{l}\text { Sycophila variegata } \\
\text { (Curtis) }\end{array}$} & $\begin{array}{l}\text { FRANCE: Corsica, Ghisonacchia, } 10 \mathrm{~m} \text {, } \\
\text { swept from Pistacia lentiscus }\end{array}$ & 10 & 3 & 3 & P17-P18-P19 \\
\hline & $\begin{array}{l}\text { IRAN: Lorestan, Ghalai, ex Chilaspis israeli } \\
\text { on Quercus brantii }\end{array}$ & 3 & 1 & 3 & H176- H181- H182 \\
\hline
\end{tabular}

* Identification was based on the morphological characters indicated by the initial morphological study.

our observations suggest that $S$. pistacina is univoltine. Although Megastigmus pistaciae is bivoltine in Iran (Davatchi, 1956), it seems to be mostly univoltine in the western Mediterranean Basin (Grissell \& Prinsloo, 2001; pers. observ.). We observed females of $S$. pistacina flying around clusters of Pistacia and ovipositing in the pods in late summer (August-September) while the host pupates at this time (Grissell \& Prinsloo, 2001). Third, the biogeographical history of the associated plants is very different. The genus Pistacia belongs to the Anacardiaceae, a tropical family of plants. P. lenticus is even considered to be a relict component of the Tertiary subtropical flora present in the Mediterranean Basin (Axelrod, 1975) and known from the Oligocene-Miocene period (35-40 millions years bp). Its life-cycle and reproductive strategy retain archaic features characteristic of tropical plants (Verdú \& García-Fayos, 2002). In addition, the genus Pistacia supposedly originated from Central Asia (Parfitt \& Badenes, 1997). Conversely, European deciduous oaks are important components of temperate forests. They belong to the Quercus s. str. section, for which the center of diversification is in North America (Manos et al., 1999). In addition, the re-colonization of Europe soon after the last glaciation started from a couple of southern refuges and is therefore quite recent (Demesure \& Musch, 2001; Kremer \& Petit, 2001; Brewer et al., 2002) in contrast to the presence of Pistacia over millions of years (Axelrod, 1975). The biogeographic features of the hosts of Sycophila mimic the pattern described above for the plants. The Cynipidae are typical temperate taxa and the species associated with oaks are particularly specialized, while the Megastigmus of the pistaciae species group probably originated from Africa (Grissell \& Prinsloo, 2001).

The aims of this study are: (1) investigate the possibility of separating eurytomids belonging to the Sycophila biguttata complex into discrete entities; (2) provide reli- able features for the recognition of these entities; (3) update the nomenclature of the biguttata complex. We looked first for morphological characters and then did a morphometric study in order to confirm the reliability of the characters selected. This data was finally compared with molecular data obtained from an analysis of a couple of genes. This study is a part of a revision of the European Eurytomidae undertaken by GD.

\section{MATERIAL AND METHODS}

\section{Collecting sites and sampling}

Several dozens of specimens were used in the morphological study. They were collected in Corsica, France, Hungary, Iran, Spain and the Netherlands. Specimens identified as S. biguttata were reared from cynipid galls on Quercus pubescens and $Q$. brantii. Those identified as $S$. pistacina were collected from Pistacia terebinthus or P. lentiscus, together with Megastigmus pistaciae; specimens of $S$. iracemae were mostly collected from $Q$. pubescens and determined by morphological comparison with paratypes; they were not directly associated with cynipid galls. $S$. biguttata was identified by comparison with a series housed in the BMNH and identified as such by Claridge.

Twenty five fresh specimens of S. biguttata and S. pistacina and two specimens of $S$. iracemae were used for the morphometric and molecular studies (Table 1). After removing fore wings and hind legs for mounting on slides and measuring, the rest of the body was preserved in $95 \% \mathrm{EtOH}$ at $-20^{\circ} \mathrm{C}$ and used for the genetic study. Eurytoma amygdali Enderlein, Eurytoma caninae Lotfalizadeh \& Delvare (Lotfalizadeh et al., 2007) and Sycophila variegata (Curtis) were used as outgroups.

Abbreviations: BMNH - Natural History Museum, London, UK; CBGP - Centre de Biologie pour la Gestion des Populations, Montferrier-sur-Lez, France; GD - Gérard Delvare personal collection, Montpellier, France; OXUM - Hope Department, Oxford University, Oxford, UK; IEE - Instituto Español de Entomología, Madrid, Spain; INRA - Institut National de la Recherche Agronomique, Montpellier, France; MZLU - Lund University, Zoological Museum, Lund, Sweden; 

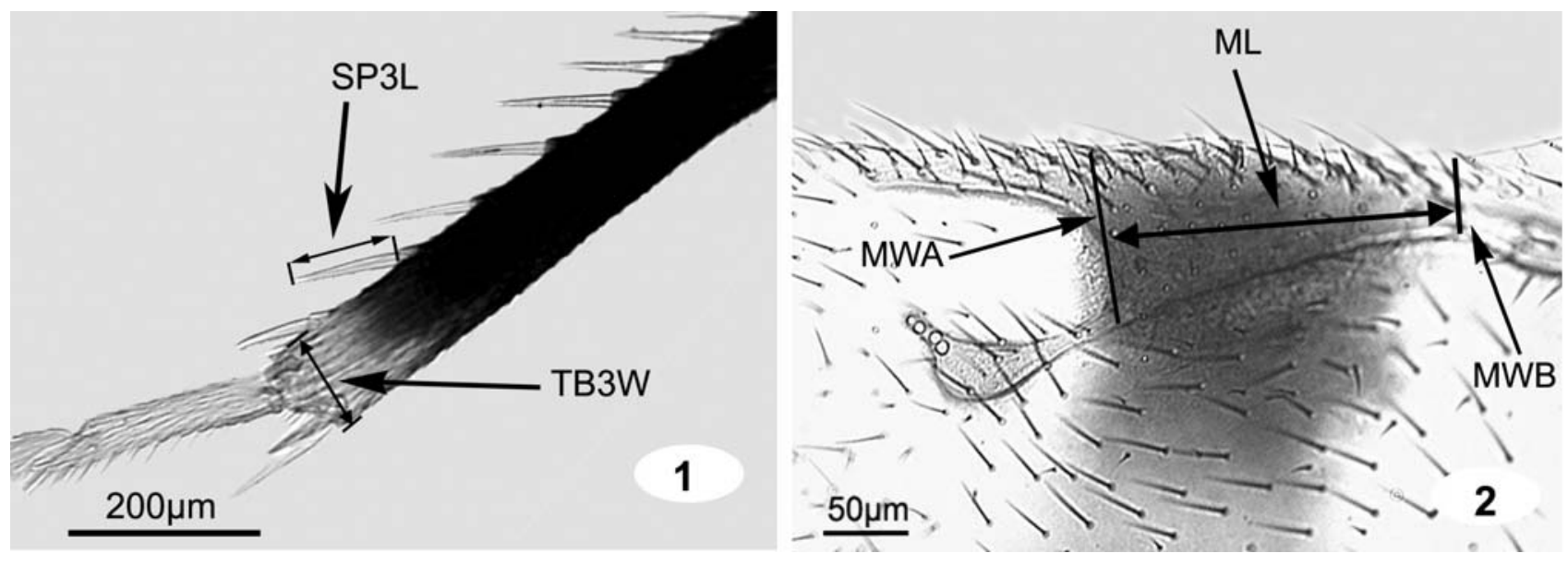

Figs 1-2. Sycophila biguttata complex, the characters measured. 1 - hind tibia; 2 - fore wing. Abbreviations: ML - length of marginal vein; MWA - width of marginal vein at apex; MWB - width of marginal vein at base; SP3L - length of penultimate spiniform seta on hind tibia; TB3W - width of hind tibia at apex.

MZUF - Natural History Museum of the University of Firenze Zoological Section "La Specola".

\section{Morphometric study}

Initially eight characters (Table 2) of the two hypothesized groups, respectively identified as $S$. biguttata and S. pistacina, were analyzed quantitatively. Width and length measurements indicate maximum dimensions unless stated otherwise. These dimensions were measured between homologous points on all specimens regardless of treatment (Figs 1-2). The base of the marginal vein could not be identified because the parastigma continues to the marginal vein and there is no evident angle between the two veins. The end of the colorless region of the parastigma was considered to be the distal limit of the parastigma (Fig. 2). All measurements were made with a Leica DMRD stereo-microscope and the LEICA QWin ${ }^{\circledR}$ software.

Measurements were log-transformed to allow for allometry and to normalize distributions. They were not size-standardized because size is an important taxonomic criterion, related with ecological correlates such as habitat selection and food regime. Size must be considered together with shape in morphometric studies.

After discarding the variance-covariance PCA (Principal Component Analysis) owing to differences in variance, standard PCAs using correlation matrices based on a $50 \times 5$ matrix were performed. Differences in shape between species were analyzed in different ways: (i) by looking to the eigenvectors following the first ones in the preceding PCA; (ii) by performing a PCA

TABLE 2. Characters used in the morphometric study.

I - Simple characters (linear measurements):

$1-\mathrm{ML}=$ Length of marginal vein (Fig. 2)

$2-$ MWB $=$ Width of marginal vein at base (Fig. 2)

$3-$ MWA $=$ Width of marginal vein at apex (Fig. 2)

$4-\mathrm{SP} 3 \mathrm{~L}=$ Length of penultimate spiniform seta on hind tibia (Fig. 1)

$5-\mathrm{TB} 3 \mathrm{~W}=$ Width of hind tibia at apex (Fig. 1)

II - Ratio characters:

$6-$ RMW $=$ Ratio width of marginal vein at base and apex (MWA : MWB)

$7-$ RML $=$ Ratio length of marginal vein to width of marginal vein at apex (ML : MWA)

$8-$ RST $=$ Ratio width hind tibia/length penultimate spiniform seta (SP3L : TB3W) on three log-transformed ratios calculated from the primary variables (as ratios can be useful in morphometry despite allometry and autocorrelation problems); (iii) by performing a correspondence analysis $(\mathrm{CA})$ on the $50 \times 5$ matrix. In $\mathrm{CA}$, the standardisation of the variable values by their sum for each individual simply and efficiently removes most of the size effects and the results are similar to a doubly centred PCA.

Furthermore, MANOVA was used to determine the morphological separation of two species. It allows separation of the two species on the basis of a linear combination of dependant variables.

Statistical analysis of the data was carried out using Statistica (StatSoft). The mean values of all characters were compared using a Student's t-test with $\alpha=0.05$.

Our sample of fresh $S$. iracemae specimens was too small for a combined morphometric/molecular study. A special quantitative study, which only considered the relative proportion of the head (width and height) provided additional information. For this, dried specimens of the three above species were used. They were segregated on the basis of characters validated in the morphological study.

\section{Molecular study}

\section{DNA extraction}

Sources of DNA included 50 specimens of adults preserved in $95 \%$ ethanol and stored in a freezer at $-20^{\circ} \mathrm{C}$. The mitochondrial Cytochrome Oxidase I (COI) and nuclear Internal Transcribed Spacer 2 (ITS2) were used as genetic markers.

Genomic DNA was isolated by using the following protocol: first, single individuals were removed from ethanol and ground in an ependorf tube containing $50 \mu \mathrm{l}$ CTAB buffer $(2 \%$ CTAB, 1.4 M NaCI, $100 \mathrm{mM}$ Tris- $\mathrm{HCl}$ (pH 8), 20 mM EDTA and 0.2\% 2-mercaptoethanol); after which $150 \mu 1$ of CTAB was added to each tube. Specimens in CTAB buffer were incubated at $65^{\circ} \mathrm{C}$ for $50 \mathrm{~min}$. Proteins were removed by adding chloroform isoamyl alcohol and centrifugation for $10 \mathrm{~min}$ at $13,000 \mathrm{rpm}$. The supernatant was transferred to a clean tube and $150 \mu \mathrm{l}$ cold isopropanol added and vortex-mixed. After precipitation for 60 min at $-20^{\circ} \mathrm{C}$, extracts were re-centrifuged for $30 \mathrm{~min}$ at $4^{\circ} \mathrm{C}$ and 13,000 rpm. The proteins were cleaned with $500 \mu 1$ absolute ethanol then centrifuged for $10 \mathrm{~min}\left(4^{\circ} \mathrm{C}\right.$ and $\left.13000 \mathrm{rpm}\right)$. Finally, DNA was resuspended in $30 \mu \mathrm{l}$ of distilled water. 


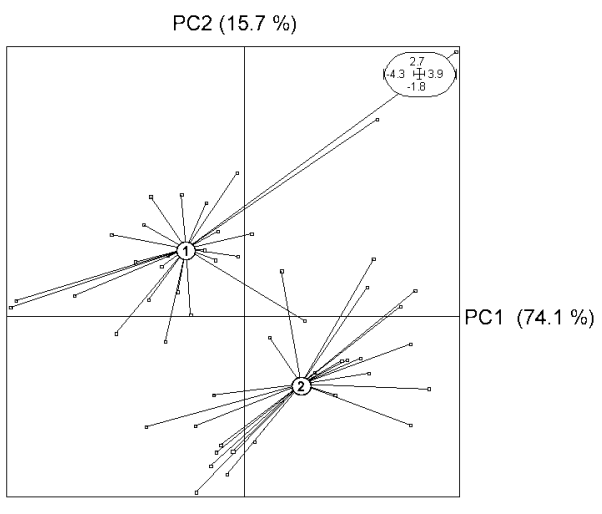

Fig. 3. Star shape of the first two principal components (PC1-PC2) from the principal component analysis of five of the linear characters from log-transformed data set. Groups 1 and 2 define a priori taxa, $S$. biguttata and $S$. pistacina, respectively.

PCR amplification, purification, and sequencing of mtDNA COI and rDNA ITS2

Insect primers were used to amplify $1307 \mathrm{bp}$ from mitochondrial COI and nuclear ITS2. Primers for the PCR were: COI forward primer (5'-GGT CAA CAA ATC ATA AAG ATA TTG G-3') (Lunt et al., 1996) and reverse primer (5'-TCC ATT GCA CTA ATC TGC CAT ATT A-3') (Simon et al., 1994). ITS2 forward primer (5'-TGT GAA CTG CAG GAC ACA TG-3') and reverse (5'-AAA TGC TTA AAT TTA GGG GGT A-3') (Campbell et al., 1993).

PCR reactions for COI $(25 \mu \mathrm{l})$ contained $1 \mathrm{X}$ enzyme Buffer (Qiagen ${ }^{\circledR}$ ), $1.5 \mathrm{mM} \mathrm{MgCl}, 0.625$ unit of Taq polymerase, 0.7 $\mu \mathrm{M}$ of each primer, $0.2 \mathrm{mM}$ of dNTP and $1 \mu \mathrm{l}$ of DNA extract (0.5× SolutionQ, for COI), and carried out on a PTC-200 thermocycler. DNA was denatured for $3 \mathrm{~min}$ at $94^{\circ} \mathrm{C}$, followed by 40 amplification cycles comprising $30 \mathrm{~s}$ denaturing at $92^{\circ} \mathrm{C}$, $90 \mathrm{~s}$ annealing at $52^{\circ} \mathrm{C}$ and $120 \mathrm{~s}$ extension at $72^{\circ} \mathrm{C}$. DNA was finally extended for $10 \mathrm{~min}$ at $72^{\circ} \mathrm{C}$ after amplification.

The same conditions were used for the PCR amplification of ITS2, with following changes: denaturation for $2 \mathrm{~min}, 30$ amplification cycles, $1 \mathrm{~min}$ denaturing at $94^{\circ} \mathrm{C}$ and $1 \mathrm{~min}$ annealing at $45^{\circ} \mathrm{C}$.

PCR products were separated on a $1.5 \%$ agarose gel. Purified DNA fragments were directly sequenced from both directions using an automated sequencer at CBGP. Primers used for amplification also served as sequencing primers.

All of the taxa used in this study are represented by secondary voucher specimens deposited in the INRA collection at Montpellier, France.

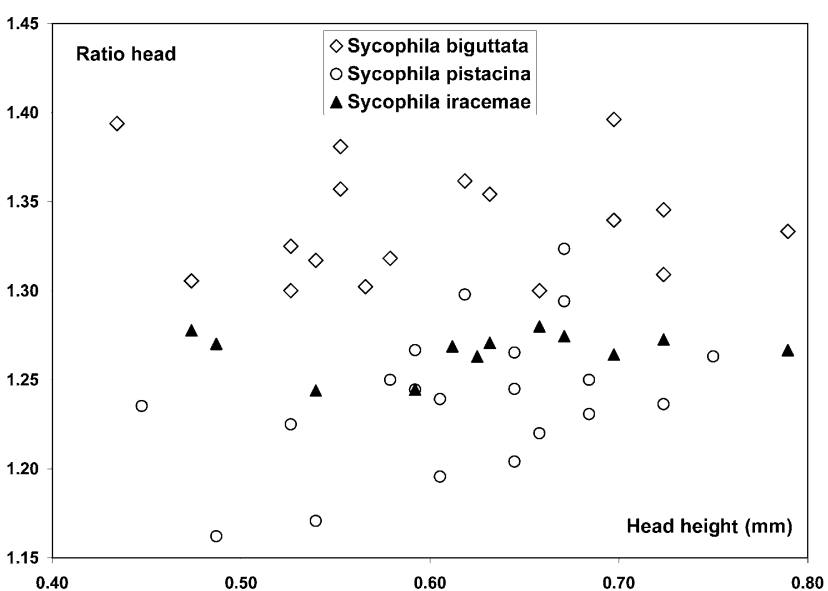

Fig. 4. Scatterplot of the head ratio "width/height" and "head width" for S. biguttata, S. iracemae and S. pistacina.

\section{Sequence alignment}

The alignment of the COI and ITS2 sequences was done with CLUSTAL (Thompson et al., 1997). The computer package BioEdit 7.0.5 (Hall, 2005) was used for manual inspection and correction of sequences according to the secondary structure of Drosophila yakuba. Aligned sequences were reformatted appropriately and entered into MEGA 3 (Kumar et al., 2004) for calculation of sequence statistics. Sequences were deposited in GenBank (accession numbers EU017316 to EU017329) and the aligned data matrix is available from the authors upon request.

Phylogenetic analysis

Kimura's two-parameter model of base substitution was used to calculate genetic distances with MEGA 3.1 software (Kumar et al., 2004). The mitochondrial haplotypes and ITS2 sequences were analyzed separately with maximum parsimony (MP) and neighbour-joining (NJ) analysis using PAUP*4.0b10 (Swofford, 2001). MP was carried out through branch and bound search. Support for monophyly of clades was assessed by bootstrap values (Felsenstein 1985) with 1000 replicates (full heuristic search) using PAUP*. NJ analyses involved the K2P distance model (Kimura, 1980), but the results did not change with use of other models.

\section{RESULTS}

\section{Morphology (Figs 5-16)}

Sycophila biguttata, S. pistacina and S. iracemae are very similar. In side-by-side comparisons 2 qualitative and 3 quantitative characters placed specimens into 2 discrete groups, with $S$. pistacina and $S$. iracemae morpho-

TABLE 3. Morphological characters separating S. pistacina from S. biguttata.

\begin{tabular}{|c|c|c|}
\hline Characters & S. biguttata & S. pistacina \\
\hline Ratio head width : head height & over 1.3 (Fig. 5) & $\begin{array}{l}\text { generally below } 1.27 \\
\text { exceptionally over } 1.3 \text { (Fig. } 6 \text { ) }\end{array}$ \\
\hline Intertorular projection & $\begin{array}{l}\text { narrow but not carinate, distinctly pilose } \\
\text { (Figs } 7,8)\end{array}$ & $\begin{array}{c}\text { carinate above and barely pilose } \\
\text { (Fig. 11) }\end{array}$ \\
\hline $\begin{array}{l}\text { Propodeum: basal sculpture of median } \\
\text { furrow }\end{array}$ & 2 rows of areoles (Fig. 10) & 1 row of areoles (Fig. 11) \\
\hline $\begin{array}{l}\text { Length of spiniform setae on hind tibia } \\
\text { relative to width of hind tibia at distal end }\end{array}$ & shorter (Fig. 15) & generally longer (Fig. 16) \\
\hline Marginal vein & front and hind margins parallel (Fig. 12) & $\begin{array}{l}\text { front and hind margins distally diverging } \\
\text { (Fig. 13) }\end{array}$ \\
\hline
\end{tabular}



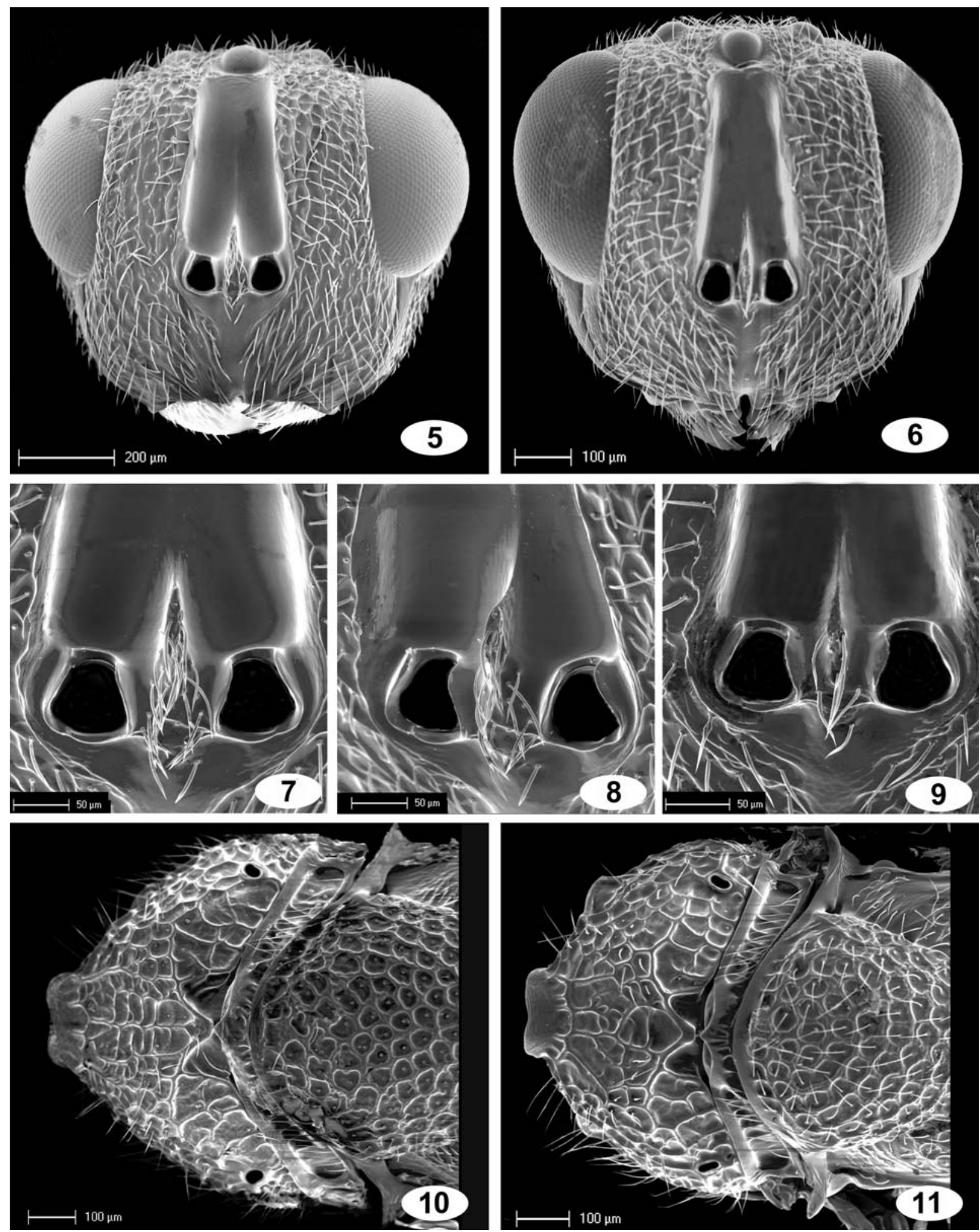

Figs 5-11. 5, 7, 8, 10 - Sycophila biguttata. 6, 9, 11 - Sycophila pistacina. 5, 6- head in frontal view; 7-9 - intertorular space; 10,11 - propodeum and scutellum in dorsal view.

logically indistinct. These characters are presented in Table 3. See also Figs 5-16. The intertorular projection in S. biguttata is slightly wider than in S. pistacina and $S$. iracemae. In these latter two species the intertorular projection is narrow, sharp and carinate above. It is also more distinctly pilose in S. biguttata, bearing 15-22 hairs while 6-8 hairs are visible in the other species (Figs 7-9). The median furrow of the propodeum is also different. In $S$. biguttata two rows of areoles are visible because a median ridge is present. In S. pistacina and S. iracemae, the ridge is absent and only one row of areoles can be seen (Figs 10-11). 

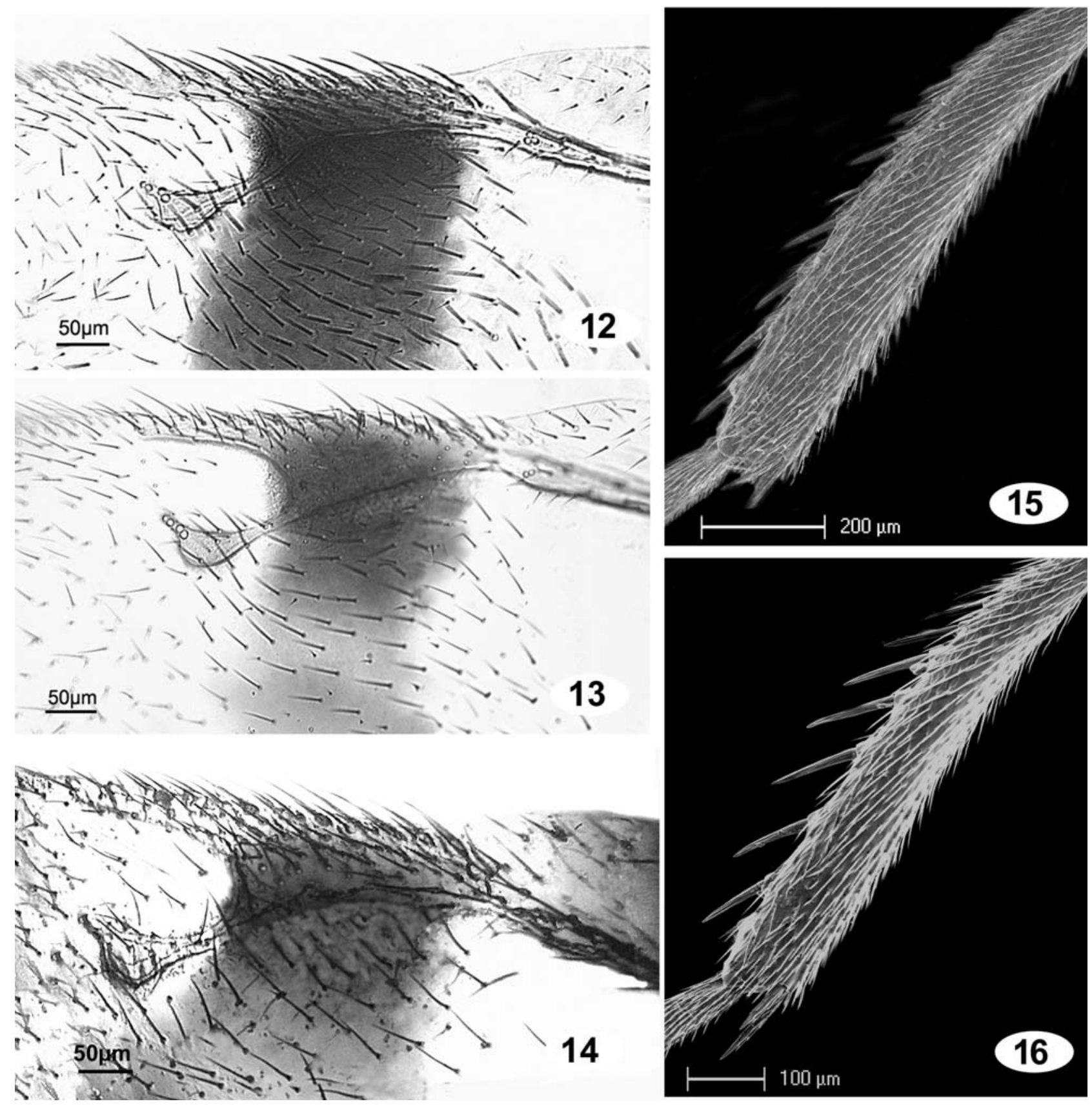

Figs 12-16. 12, 15 - Sycophila biguttata. 13, 16 - Sycophila pistacina. 14 - S. iracemae. 12-14 - fore wing venation; 15-16 hind tibia in lateral view.

Morphological characters that discern the three species include the relative proportions of head, shape of marginal vein and relative length of dorsal spiniform setae on hind tibia. The anterior and posterior margins of marginal vein diverge in S. pistacina (Fig. 13), while they are subparallel in S. biguttata (Fig. 12). The spiniform setae are longer than width of tibia in the former species (Fig. 16) and at most as long as that width in the latter (Fig. 15).

However, S. pistacina can hardly be distinguished from $S$. iracemae. Only its marginal vein is slightly more thickened with the anterior and posterior margins diverging rather more sharply, and the vein is overall somewhat shorter (Figs 13-14). However these characters intergrade; they are very difficult to discern without experi- ence and require a reference collection. The relative proportions of the head can also be used (Fig. 4). In S. iracemae, the ratio of width/head height is $1.3-1.4$, whereas in $80 \%$ of the specimens of S. pistacina it does not reach 1.25; unfortunately this ratio seems more susceptible to allometry and in a few cases it exceeds 1.30.

\section{Morphometric study}

Principal Component Analysis of the morphological variables resulted in a highly significant discrimination of the species. This analysis, using 7 characters (the length of marginal vein was rejected), provides strong statistical support for reliable species discrimination. In all but few 
TABle 4. Univariate statistics, in micrometers, of the simple characters used in the morphometric analysis of Sycophila spp.

\begin{tabular}{lcccccccc}
\hline \multirow{2}{*}{ Character } & \multicolumn{3}{c}{ S. biguttata } & & \multicolumn{3}{c}{ S. pistacina } \\
\cline { 2 - 3 } \cline { 7 - 8 } & Mean & Min & Max & & Mean & Min & Max \\
\hline ML & 177.52 & 146.63 & 266.26 & & 173.09 & 148.74 & 203.17 \\
MWB & 48.16 & 38.05 & 69.09 & & 53.10 & 40.34 & 65.34 \\
MWA & 87.71 & 66.93 & 112.13 & & 106.87 & 83.45 & 134.32 \\
SP3L & 69.40 & 57 & 89 & & 98.68 & 80.85 & 116.07 \\
TB3W & 76.19 & 60.65 & 106.8 & & 89.01 & 70.68 & 107.72 \\
\hline
\end{tabular}

marginal cases the species can be directly separated using the proposed ratios.

Marginal separation was obtained between S. biguttata and $S$. pistacina based on the first and second components (PC1 \& PC2) (Fig. 3). Although the remaining components in each analysis contained a significant proportion $(8 \%)$ of the variance, they had no more diagnostic value than the first two components. The first component has high loadings of all variables $(92 \%)$ and is assumed to represent size. The variable with a high loading on the first component was the length of the hind tibial spiniform seta, which is consistent with the univariate separation involving this variable. Univariate measurements, along any particular axis, are either overlapping or very marginally separate species (Table 4), exemplifying the problems associated with separating species by individual measurements.

More distinctive non-overlapping differences occur using a combination of characters. Two species (S. biguttata and $S$. pistacina) are distinct in all the bivariate plots. In spite of overlap in some of the studied characters, the ratio of the penultimate spiniform seta length to width of hind tibia (SP3L/TB3W) and length of marginal vein to its width at the apex (ML/MWA) is probably the best way to separate them (Table 6). There is a narrow zone of overlap between the two species in the range of the 3 ratios, which may be the result of their close relationship.

\section{Molecular study}

We obtained 18 and 19 sequences respectively for COI and ITS2 (Table 1). DNA variation between and within species of $S$. biguttata and $S$. pistacina was examined in a 814 bp segment of the mitochondrial COI and 493 bp segment of the nuclear ITS2.

\section{COI}

One sequence, $593 \mathrm{bp}$ in length, included only half of this region. Including or excluding these shorter

TABLE 5. Eigenvalues and weights for the first two principal components, computed from the covariance matrix of the logtransformed data of two types of characters.

\begin{tabular}{lccc}
\hline Character & Type of character & PC1 & PC2 \\
\hline \multirow{2}{*}{ Eigenvalue } & Simple & 3.7133 & 8.9298 \\
& Ratio & 2.2242 & 4.7079 \\
Proportion of variance & Simple & 0.7427 & 0.1786 \\
& Ratio & 0.7414 & 0.1569 \\
\hline
\end{tabular}

TABLE 6. Ranges (mean) of ratios plotted in Figs 1-2.

\begin{tabular}{lccc}
\hline Character ratio & S. biguttata & S. pistacina & S. iracemae \\
\hline RMW & $1.63-2.27$ & $1.70-2.44$ & $1.66-2.27$ \\
(MWA/MWB) & $(1.83)$ & $(2.03)$ & $(1.96)$ \\
RML & $1.40-2.37$ & $1.53-1.85$ & $1.76-1.90$ \\
(ML/MWA) & $(2.03)$ & $(1.63)$ & $(1.83)$ \\
RST & $0.94-0.99$ & $0.98-1.05$ & $1.00-1.07$ \\
(SP3L/TB3W) & $(0.97)$ & $(1.02)$ & $(1.03)$ \\
Head ratio & $1.30-1.39$ & $1.16-1.32$ & $1.30-1.39$ \\
(W/H)* & $(1.34)$ & $(1.24)$ & $(1.34)$ \\
\hline
\end{tabular}

* This character was added in a second step of the quantitative study and not used in the morphometric analyses.

sequences did not substantially affect any of the results reported below because every species is represented by at least one long sequence. Of the 814 nucleotide sites in the dataset, $206(25.3 \%)$ were variable and 151 (18.6\%) parsimony informative. The second codon position with $89.8 \%$ of the non-variable sites is the most constant. The third codon position is highly variable with only $29.6 \%$ constant sites. The average frequency of $\mathrm{A}+\mathrm{T}$, variable sites and parsimony informative sites are the highest for the third codon position, respectively $90.2 \%, 66.7 \%$ and $66.5 \%$, (Table 7).

Minimal intraspecific variation was observed within the $S$. iracemae $(=0 \%), S$. pistacina $(=0.1 \%)$ and $S$. biguttata $(=0.2 \%)$ populations. The pairwise distances of species pairs showed that the maximum divergence (18.5\%) is between $S$. pistacina and E. caninae and minimum divergence between $S$. iracemae and $S$. pistacina $(0.5 \%)$ (Table 8).

\section{ITS2}

The lengths of the regions analyzed range from 447 to $483 \mathrm{bp}$ (553 bp including indels). The sequences of $E$. amygdali, E. caninae, S. biguttata, S. iracemae, S. pistacina and S. variegata were 483, 468, 461-479, 479, 479-480 and $447 \mathrm{bp}$ long, respectively. The largest of the indels was $29 \mathrm{bp}$ and found in $S$. variegata.

Of the $553 \mathrm{bp}, 451(81.6 \%)$ characters are constant and the number of parsimony-informative characters is 54 $(9.8 \%)$. The composition of each base was relatively homogeneous (Table 7). The average frequency of $\mathrm{A}+\mathrm{T}$ nucleotides in ITS2 $(54.1 \%)$ is lower than in the COI gene $(74.5 \%)$.

The interspecific divergence ranges from $0.3 \%$ to $12.2 \%$ (Table 8); no intraspecific divergence was found. The genetic distance ingroup-outgroup ranges from 7.6 to $12.2 \%$.

\section{Phylogenetic relationships}

Whatever gene is considered, the specimens initially identified as $S$. pistacina branch on a node different from specimens attributed to $S$. biguttata. The species are hence clearly distinct. $S$. pistacina together with $S$. iracemae form a monophyletic and well supported group. With COI, the pair of specimens a priori identified as $S$. iracemae group together, supported by a high bootstrap value $(95 \%)$. The genetic divergence from $S$. pistacina is very slight $(0.9-1.0 \%)$. For ITS2, the two populations are 
TABLE 7. Summary of nucleotide composition (\%) and number of variables sites in the COI and ITS2 data of the Sycophila species examined.

\begin{tabular}{clcccccccc}
\hline & & Base pairs & T & C & A & G & A + T & Variable sites & Parsimony informative \\
\hline \multirow{4}{*}{ COI } & all & 814 & 46.3 & 9.4 & 28.2 & 16.1 & 74.5 & 206 & 151 \\
& Pos \#1 & 272 & 34.3 & 9.8 & 32.2 & 23.7 & 66.5 & $40(19.4 \%)$ & $25(16.6 \%)$ \\
& Pos \#2 & 271 & 46.8 & 17.0 & 19.9 & 16.3 & 66.7 & $21(10.2 \%)$ & $17(11.2 \%)$ \\
& Pos \#3 & 271 & 57.8 & 1.3 & 32.4 & 8.4 & 90.2 & $145(70.4 \%)$ & $109(72.2 \%)$ \\
\hline \multirow{2}{*}{ ITS2 } & \multirow{2}{*}{ all } & \multirow{2}{*}{$447-483$} & 27.6 & 22.1 & 26.5 & 23.8 & 54.1 & $63-92$ & $43-52$ \\
& & & & & & & & & \\
\hline
\end{tabular}

mixed. The fact that $S$. pistacina exhibits no intraspecific variation is surprising, as one population was collected in the island of Corsica, which has been isolated from the mainland for a long time. Is this species quite stable genetically? Or was it recently introduced? S. pistacina + $S$. iracemae is a sister group of $S$. variegata using COI and of $S$. biguttata using ITS2. The first relationship is better supported by the bootstrap (100 versus 85 ) but conflicts with the overall morphology, as $S$. pistacina and $S$. biguttata are relatively similar.

\section{CONCLUSION}

Sycophila biguttata and S. pistacina, although superficially similar, are clearly distinct species. They can be discriminated by several morphological characters, some of them having been confirmed by morphometry. Moreover, the genetic evidence provided by the sequencing of two genes unambiguously confirms the separation of these species.

The distinction between $S$. pistacina and $S$. iracemae, either on morphological characters or morphometric variables, is much more problematic. However, we are reluctant to synonymize both names as the species exhibit quite distinct biologies and hosts. S. pistacina is definitively associated with Pistacia spp. and their chalcid seed-eater, $M$. pistaciae; the species is monovoltine, at least in Western Europe, and adults occur from July to October with maximum activity in August-September. $S$. iracemae is a parasitoid of the agamous generation of a few Andricus spp. (A. kollari and A. coriarius) galling deciduous oaks and apparently of the sexual form of Pediaspis aceris on Acer spp.; nevertheless further data are required to confirm this latter assessment. The adults occur from May to October and therefore a second generation might be produced. Further molecular data, based on populations reared under the same conditions as the holotype, are required to precisely resolve the status of $S$. iracemae.

The phylogeny of the whole complex is presently unresolved as the topologies achieved with COI and ITS2 do not coincide. A larger sample of the biguttata species group including populations of $S$. submutica (Thomson) and further populations of $S$. variegata is necessary to resolve this problem. At present it is only possible to indicate that the genes in the respective populations of $S$. biguttata and S. pistacina are quite stable.

TABLE 8. Divergence (below the diagonal) and number of differences (above the diagonal) in the COI and ITS2 sequences based on pair-wise comparisons among populations of the Sycophila biguttata complex and outgroups (2 Eurytoma spp.). Abbreviations. Eamyg - Eurytoma amygdali from Syria; Ecani - Eurytoma caninae from Iran; Syva - S. variegata; Sycir - S. iracemae from France; SybiF - S. biguttata from France; SybiI - S. biguttata from Iran; SypiF - S. pistacina from Southern France (Hérault); SypiC - S. pistacina from Corsica.

\begin{tabular}{lcccccccc}
\hline COI & Eamyg & Ecani & Syva & Sycir & SybiF & SybiI & SypiF & SypiC \\
\hline Eamyg & - & 90 & 131 & 130 & 107 & 107 & 126 & 126 \\
Ecani & 0.110 & - & 146 & 151 & 123 & 123 & 146 & 145 \\
Syva & 0.160 & 0.179 & - & 28 & 120 & 120 & 22 & 21 \\
Sycir & 0.159 & 0.185 & 0.034 & - & 110 & 110 & 4 & 5 \\
SybiF & 0.131 & 0.151 & 0.147 & 0.135 & - & 2 & 108 & 109 \\
SybiI & 0.131 & 0.151 & 0.147 & 0.135 & 0.002 & - & 108 & 109 \\
SypiF & 0.154 & 0.179 & 0.027 & 0.005 & 0.132 & 0.132 & - & 1 \\
SypiC & 0.154 & 0.178 & 0.026 & 0.006 & 0.134 & 0.134 & 0.001 & - \\
\hline ITS2 & Eamyg & Ecani & Syva & Sycir & SybiF & SybiI & SypiF & SypiC \\
\hline Eamyg & - & 48 & 42 & 62 & 51 & 51 & 62 & 62 \\
Ecani & 0.082 & - & 32 & 35 & 36 & 36 & 34 & 34 \\
Syva & 0.106 & 0.076 & - & 15 & 16 & 16 & 14 & 14 \\
Sycir & 0.103 & 0.076 & 0.019 & - & 17 & 0 & 1 & 1 \\
SybiF & 0.122 & 0.091 & 0.030 & 0.022 & - & - & 16 & 16 \\
SybiI & 0.122 & 0.091 & 0.030 & 0.022 & 0.000 & 0.019 & - & 16 \\
SypiF & 0.103 & 0.073 & 0.016 & 0.003 & 0.019 & 0.019 & 0 \\
SypiC & 0.103 & 0.073 & 0.016 & 0.003 & 0.019 & 0.019 & 0.000 & - \\
\hline
\end{tabular}



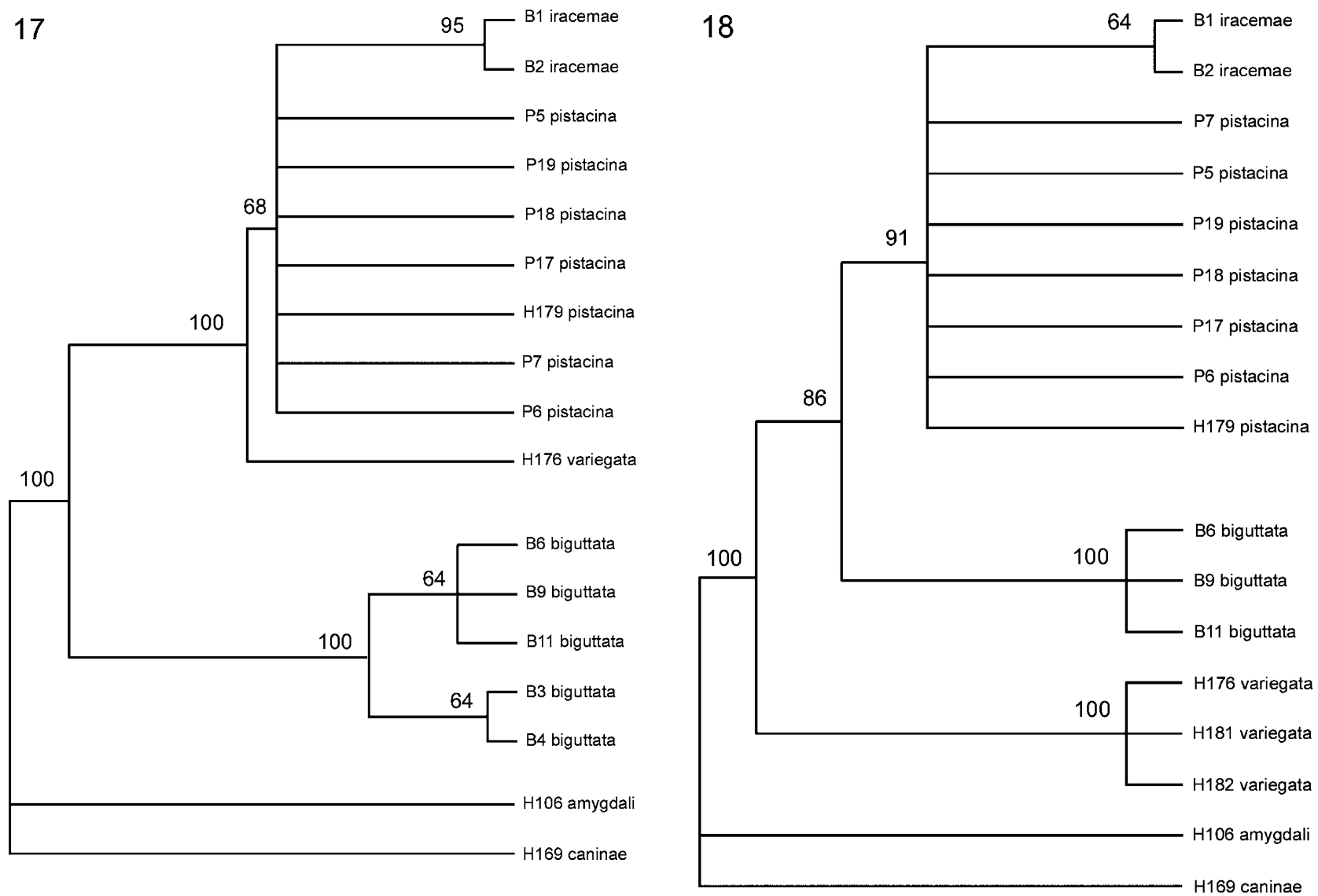

Figs 17-18. Phylogenetic trees based on neighbour-joining and parsimony: 17 - COI; 18 - ITS2. Specimen references as quoted in Table 1. Bootstrap values calculated in parsimony are figured above branches.

\section{UPDATED NOMENCLATURE OF THE BIGUTTATA COMPLEX AND NEW DATA CONCERNING THE DISTRIBUTION OF S. IRACEMAE}

\section{Sycophila biguttata (Swederus, 1795)}

Pteromalus biguttatus Swederus, 1795: 216. Type locality: Sweden. Type status: type probably lost; interpretation of authors follows that of Boheman. Specimens in the Boheman collection in Stockholm examined by Claridge, 1959: 155.

Eurytoma biguttata (Swederus): Dalman, 1820: 177.

Decatoma biguttata (Swederus): Curtis, 1831: 345 n²

Decatoma cooperi Curtis, 1831: 1. Type locality: UK. Downgraded to variety by Dalla Torre, 1898: 326 . Synonymy by Claridge, 1959: 154-156. One syntype (in OXUM) examined by Claridge, 1959: 155. Other syntypes in the Curtis collection housed in Melbourne.

Decatoma obscura Curtis, 1831: $345 \mathrm{n}^{\circ}$ 4. Type locality: UK. Downgraded to variety by Dalla Torre, $1898: 327$. Synonymy by Mayr, 1905: 543. Type status: lectotype designation by Claridge, 1959: 156 (BMNH).

Cinips (!) fasciata Fonscolombe, 1832: 288. Type locality: France. Synonymy by Graham, 1992: 1100. Type status: lectotype designation by Graham, 1992: 1100 (OXUM).

Decatoma immaculata Walker, 1832: 27. Type locality: UK. Downgraded to variety by Dalla Torre, $1898: 327$. Synonymy by Mayr, 1905: 543. Type status: 3 females syntypes (in BMHN) examined by Claridge, 1959: 156, but species description based on male.

?Decatoma plana Walker, 1832: 27. Type locality: UK. Claridge, 1959: 156 considered the name most likely a junior synonym of $S$. biguttata. Type status unknown.
Decatoma semifasciata Walker, 1834: 156. Type locality: France. Synonymy by Claridge, 1959: 154. Type status: 1 female syntype (in BMHN) examined by Claridge, 1959: 156. Other syntypes not found.

?Decatoma flavicornis Walker, 1836: 25. Type locality: UK. Claridge, 1959: 156 considered the name most likely a junior synonym of $S$. biguttata. Type status unknown.

Eurytoma signata Nees, 1834: 43. Type locality: Germany. Synonymy by Graham, 1988: 23. Type status: lectotype designation by Graham, 1988: 23 (OXUM)

Decatoma inequalis Thomson, 1876: 32. Type locality: Sweden. Synonymy by Claridge, 1959: 154. Type status: lectotype designation by Claridge, 1959: 156 (MZLU)

Decatoma incrassata Thomson, 1876: 31-32. Type locality: Sweden. Synonymy by Claridge, 1959: 154. Type status: lectotype designation by Claridge, 1959: 156 (MZLU)

Decatoma strigifrons Thomson, 1876: 32. Type locality: Sweden. Synonymy by Mayr, 1905: 543. Type status: lectotype designation by Claridge, 1959: 156 (MZLU)

Eudecatoma biguttata (Swederus): Claridge, 1959: 154.

Sycophila biguttata (Swederus): Bouček, 1974: 263.

\section{Sycophila pistacina (Rondani, 1872) new combination}

Tineomyza pistacina Rondani, 1872: 205. Type locality: Sicily. Synonymized with Sycophila biguttata by Bouček, 1974: 263. Type status: lectotype designation by Bouček, 1974: 263 (MZUF).

Decatoma trogocarpi De Stefani, 1908. New synonymy. Type locality: Sicily. Type status unknown. Eudecatoma trogocarpi De Stefani: Ferrière, 1968: 242. Re-description and notes on biology: Ferrière, 1968: 242-244. 
Eurytoma trogocarpi (De Stefani): Noyes, 2002.

Eudecatoma mallorcae Hedqvist, 1962: 212. Type locality: Mallorca. New synonymy. Synonymized with $S$. biguttata by Bouček, 1974: 263.

We did not examine the type of Decatoma trogocarpi. It is quite evident from its distribution and biology that it is the same as S. pistacina. Ferrière (1968) re-described the species and underlined some of the characters quoted in the present paper to separate it from S. biguttata. The species is erroneously included in Eurytoma by Noyes (2002). We examined the type series of E. mallorcae and agree with Bouček (1974), who considered it as belonging to the same species as S. pistacina.

\section{Sycophila iracemae Nieves Aldrey, 1983}

Sycophila iracemae Nieves Aldrey, 1983: 184-187. Type locality: Spain: Salamanca, Villarino de los Aires. Type status: holotype by original designation (IEE).

Material examined. Type material. $2 \rho, 2 \hat{\sigma}$ paratypes: SPAIN: Salamanca, Villanueva del Conde, ex Andricus coriarius (in IEE). Other material. Spain: $3 q$ Alicante, Rebate, 10.x.1990 (J.-Y. Rasplus) (in INRA). France: Lot, $2+$ Cahors, 7 and 21.v.1989 (H. Tussac) (in GD). Haute-Garonne, Castelmaurou, Malaise trap, 15.-30.vi.1990 (M. Tussac) (in GD). Hérault, 1 ㅇ Pégairolles-de-Buèges, 07.v.1994 (G. Delvare) (in GD); 19 Saint-Guilhem-le-Désert, les Lavagnes, 05.vii.1995 (J.-Y. Rasplus) (in INRA); 89 Saint-Martin-de-Londres, 20.-30.vii.1997 (J.-Y. Rasplus) (in INRA); 19 Ferrières-lesVerreries, 24.x.1995 (S. Meusnier) (in INRA). Lozère 19 Villefort, ex galls of Pediaspis aceris, 9.vii.2006 (G. Delvare) (in GD). Hautes-Alpes, 19 Lac de Siguret, 26.vii.1994 (J.-Y. Rasplus) (in INRA); Risoul, 9.vii.1994 (J.-Y. Rasplus) (in INRA).

ACKNOWLEDGMENTS. L. Soldati from INRA, Montpellier was especially kind and helpful in the use of SEM; he has all our thanks. Many thanks also to E. Azizkhani, Tarbiat Modarres University of Tehran, for providing specimens from his collection. We are grateful to M. Kaboli, University of Montpellier II, for his assistance in the statistical analysis of the data. Finally we thank J.L. Nieves Aldrey for the loan of the type series of $S$. iracemae.

\section{REFERENCES}

AsKew R.R. 1984: The biology of gall wasps. In Ananthakrishnan T.N. (ed.) Biology of Gall Insects. Oxford \& IBH Publishing Co., New Delhi, Bombay and Calcutta, pp. 231-271.

Askew R.R., Plantard O., Gómez J.F., Hernandez Nieves M., NIEVES-AldRey J.L. 2006: Catalogue of parasitoids and inquilines in galls of Aylacini, Diplolepidini and Pediaspidini (Hym., Cynipidae) in the West Palaearctic. Zootaxa 1301: $1-60$.

AxELROD D.I. 1975: Evolution and biogeography of MadreanTethyan sclerophyll vegetation. Ann. Missouri Bot. Gard. 62: 280-334.

Boheman C.H. 1836: Skandinaviska Pteromaliner. K. Svenska Vetensk. Akad. Handl. 1835: 220-259.

BouČEK Z. 1974: On the Chalcidoidea (Hym.) described by C. Rondani. Redia 55: 241-285.

Brewer S., Cheddadi R., Beaulieu de J.L. \& Reille M. 2002: The spread of deciduous Quercus throughout Europe since the last glacial period. Forest Ecol. Manag. 156: 27-48.

Campbell B.C., Steffen-Campbell J.D. \& Werren J.H. 1993: Phylogeny of the Nasonia species complex (Hym.: Pteromali- dae) inferred from an internal transcribed spacer (ITS2) and 28S rDNA sequences. Insect Mol. Biol. 2: 225-237.

Claridge M.F. 1959: A contribution to the biology and taxonomy of the British species of the genus Eudecatoma Ashmead (= Decatoma Auctt. nec Spinola) (Hym., Eurytomidae). Trans. Soc. Br. Entomol. 13(9): 149-168.

CuRTis J. 1831: British Entomology. Vol. 8. Privately published, London, Plates 338-385 (with text).

Dalla Torre K.W. von 1898: Catalogus Hymenopterorum hucusque descriptorum systematicus et synonymicus. V. Chalcididae et Proctotrupidae. G. Engelmann, Lepzig, 598 pp.

DaLman J.W. 1820: Försök till Uppställning af Insect-familjen Pteromalini, i synnerhet med afseen de på de i Sverige funne Arter. K. Svenska Vetensk. Akad. Handl. 41(1): 123-174, 177-182, tab VII-VIII [in Finnish].

Davatchi A. 1956 : Sur quelques insectes nuisibles au pistachier en Iran. Rev. Pathol. Végét. Entomol. Agric. Fr. 35: 2-26.

Davatchi A. 1958 : Étude biologique de la faune entomologique des Pistacia sauvages et cultivés. Rev. Pathol. Végét. Entomol. Agric. Fr. 37: 3-166.

De Stefani Perez T. 1908 : L'insetto dei Frutti del Pistacchio e Modo di Limitarne i Danni. Sciarrino, Palermo, $61 \mathrm{pp}$.

Demesure B. \& Musch J. 2001: L'évolution de la forêt française après la dernière glaciation: L'apport de la palynologie, l'archéologie et de la biologie moléculaire. In Le Perchec S., Guy P. \& Fraval A. (eds): Agriculture et Diversité des Plantes. Dossier de l'Environnement 21. INRA, Paris, pp. 23-28.

ERDös J. 1952: Observationes systematicae supra familiam Eurytomidarum. Folia Entomol. Hungar. 5: 109-128.

Felsenstein J. 1985: Confidence limit on phylogenies: an approach using the bootstrap. Evolution 39: 783-791.

FerRIÈRE C. 1968: Notes sur quelques Chalcidiens nouveaux ou peu connus (Hym.). Mitt. Schweiz. Entomol. Ges. 40: 240-248.

Fonscolombe Boyer E.L.J.H. DE 1832: Monographia chalciditum galloprovinciae circa aquas degentum. Ann. Sci. Nat. (Zool.) 26: 273-307.

Gómez J.F., Hernández Nieves M., Garrido Torres A.M., Askew R.R. \& Nieves-Aldrey J.-L. 2006: Los Chalcidoidea (Hymenoptera) asociados con agallas de cinípidos (Hymenoptera, Cynipidae) en la Comunidad de Madrid. Graellsia (Suppl.) 62: 293-331

Graham M.W.R. DE V. 1988: The remains of Nees von Esenbeck's collection of Hymenoptera in the University Museum, Oxford. Entomol. Mon. Mag. 124: 19-36.

Graham M.W.R. DE V. 1992: Hymenoptera collections of Boyer de Fonscolombe, with an account of his work and a description of the natural features of his estate. J. Nat. Hist. 26: 1089-1111.

Grissell E.E. \& Prinsloo G.L. 2001: Seed-feeding species of Megastigmus (Hymenoptera: Torymidae) associated with Anacardiaceae. J. Hymenopt. Res. 10: 271-279.

HALl T. 2005: BioEdit 7.0.5, a biological sequence alignment editor written for Windows 95/98/NT/2000/XP. http://www.mbio.ncsu.edu/BioEdit/bioedit.html

HEDQvist K.J. 1962: Eine neue Eudecatoma-Art von Mallorca (Hym. Chalc., Eurytomidae). Entomol. Tidskr. 83: 212-214.

KimURA M. 1980: A simple method for estimating evolutionary rate of base substitution through comparative studies of nucleotide sequences. J. Mol. Evol. 16: 111-120.

Kremer A. \& Petit R. 2001: L'épopée des chênes européens. In Le Perchec S., Guy P. \& Fraval A. (eds): Agriculture et Diversité des Plantes. Dossier de l'Environnement 21. INRA, Paris, pp. 133-138. 
Kumar S., Tamura K. \& Nei M. 2004: MEGA3: Integrated software for Molecular Evolutionary Genetics Analysis and sequence alignment. Briefings Bioinform. 5: 150-163.

Lotfalizadeh H., Delvare G. \& Rasplus J.-Y. 2007: Eurytoma caninae sp. n. (Hymenoptera, Eurytomidae), a common species previously overlooked with E. rosae. Zootaxa 1640: $55-68$.

Lunt D.H., Zhang D.-X., Szymura J.M. \& Hewitt G.M. 1996: The insect cytochrome oxidase I gene: Evolutionary patterns and conserved primers for phylogenetic studies. Insect Mol. Biol. 5: 153-165.

Manos P.S., Doyle J.J. \& Nixon K.C. 1999: Phylogeny, biogeography, and processes of molecular differentiation in Quercus subgenus Quercus (Fagaceae). Mol. Phylogen. Evol. 12: 333-349.

MAYR G. 1905: Hymenopterologische miszellen. IV. Verh. Zool. Bot. Ges. Wien 1905: 529-575.

Mourikis P.A., Tsourgianni A. \& Chitzanidis A. 1998: Pistachio nut insect pests and means of control in Greece. In Ferguson L. \& Kester D. (eds): Proceedings of the II International Symposium of Pistachios and Almonds (ISHS). Acta Hortic. 470: 604-611.

NeEs AB EsENBECK C.G. 1834: Hymenopterorum Ichneumonibus affinium Monographiae, genera Europaea et species illustrantes. Vol. 2. J.G. Cotta, Stuttgart, 448 pp.

Nieves-Aldrey J.L. 1983: Sobre las espècies de Sycophila Walker, asociadas con agallas de cinipidos en la Peninsula Iberica, con descripcion de una nueva especie (Hym.: Eurytomidae). Eos 59: 179-191.

NiKOL'SKAYA M.N. 1935: [Pistacia seed-eating chalcidids and their parasites (Hymenoptera, Chalcididae)]. Plant Prot. (Leningrad) 1935: 81-87 [in Russian].

NOYES J.S. 2002: Catalogue of the Chalcidoidea of the World. CD-Rom. Expert Center for Taxonomic Information, Amsterdam.

Parfitt D.E. \& Badenes M.L. 1997: Phylogeny of the genus Pistacia as determined from analysis of the chloroplast genome. Proc. Nat. Acad. Sci. USA 94: 7987-7982.

Pujade-Villar J. 1993: Sobre les espècies de Sycophila Walker, 1871, relacionades amb cinipo-cecidis recollectas sobre
Quercus i Rosa a Catalunya (Hym.: Chalcidoidea, Eurytomidae). Bull. Inst. Catal. Hist. Nat. 61: 69-79.

Rondani C. 1872: Sopra alcuni vesparii parassiti. Note. Bull. Soc. Entomol. Ital. 4: 201-208.

Simon C., Frati F., Beckenbach A., Crespi B., Liu H. \& Flook P.L. 1994: Evolution, weighting, and phylogenetic utility of mitochondrial gene sequences and a compilation of conserved polymerase chain reaction primers. Ann. Entomol. Soc. Am. 87: 651-701.

Swederus N.S. 1795: Beskrifning på et nytt genus Pteromalus ibland Insecterna, haerande til Hymenoptera. K. Svenska Vetensk. Akad. Handl. 16: 201-205, 216-222 [in Swedish].

Swofford D.L. 2001: PAUP. Phylogenetic Analysis Using Parsimony and other methods. Version 4.0 beta version. Sinauer, Sunderland, Massachusetts, USA.

Thompson J.D., Gibson T.J., Plewniak F., Jeanmoungin F. \& Higgins D.G. 1997: The Clustal-X-Windows interface: Flexible strategies for multiple sequences alignment aided by quality analysis tools. Nucl. Acids Res. 25: 4876-4882.

Thomson C.G. 1876: Skandinaviens Hymenoptera. Vol. 4. Lund, $192 \mathrm{pp}$.

Traveset A. 1993: Deceptive fruits reduce seed predation by insects in Pistacia terebinthus L. (Anacardiaceae). Evol. Ecol. 7: $357-361$

Verdú M. \& García-Fayos P. 2002: Reproductive ecology of Pistacia lentiscus L. (Anacardiaceae): an evolutionary anachronism in the mediterranean shrubland. Rev. Chil. Hist. Nat. 75: $57-65$.

WalKer F. 1832: Monographia Chalciditum. Entomol. Mag. 1: $12-29$.

WALKer F. 1834: Monographia Chalciditum. Entomol. Mag. 2: $148-179$.

WALKER F. 1836: Monographia Chalciditum. Entomol. Mag. 4: 9-26.

Zerova M.D. 1995: [The Parasitic Hymenoptera Subfamilies Eurytominae and Eudecatominae (Chalcidoidea: Eurytomidae) of the Palearctic.] Naukova Dumka Publishers, Kiev, 457 pp. [in Russian].

Received July 9, 2007; revised and accepted October 12, 2007 